Available online at : http://jurnal.poltekapp.ac.id/

Jurnal Manajemen Industri dan Logistik

$\perp$ ISSN (Print) 2622-528X $\mid \quad$ ISSN (Online) 2598-5795

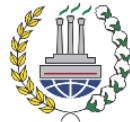

POLITEKNIK APP

JAKARTA

Logistic Management

\title{
PENERAPAN PROSES DAN TEKNIK PERAMALAN - STUDI KASUS DI MANUFAKTUR TRANSFORMER
}

\author{
APPLICATION OF FORECASTING PROCESS AND TECHNIQUES - A CASE STUDY IN A \\ TRANSFORMER MANUFACTURER
}

\author{
Elia Oey ${ }^{1}$, Gabriella Karolina Ayrine ${ }^{2}$, Purnomo Rizky Dwi Yanitra ${ }^{3}$ \\ 1,2,3 International Business Management Program, Management Department, Business School \\ Undergraduate Program, Bina Nusantara University, Jakarta, Indonesia 11480 \\ E-mail: eliaoey.binus.ac.id
}

DOI : 10.30998/jmil.v2i1.81

Peramalan permintaan sangat penting untuk proses bisnis dan keuntungan organisasi. Peramalan permintaan produk yang baik memerlukan keahlian dan kehandalan dari staff perencana. Riset in 1 adalah studi kasus di sebuah perusahaan manufaktur transformer di Indonesia, yang hendak menerapkan proses peramalan permintaan dan model peramalan yang cocok untuk produknya. Studi ini dapat memperlihatkan langkah langkah sistimati. yang diperlukan dalam meramalkan permintaan dari keempat produk yang ditelti. Untuk masing masing produk, 6 model peramalan dievaluasi dan model terbaik dipilih dengan cara mengoptimasi parameter peramalan yang memberikan kesalahan terkecil. Model peramalan yang dipilih adalah model yang sederhana tetapi cukup lengkap dilihat darl parameter tren maupun pengaruh musim yang mungkin terjadi dalam peramalan permintaan. Studi ini memberikan dasar bagi perusahaan untuk melakukan dan memonitor proses peramalan yang berkesinambungan untuk proses bisnis mereka.

Kata kunci: Peramalan, Exponential Smoothing, Hoit, Winter

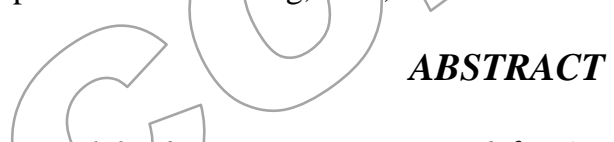

Demand forecasting is essential for business processes and firm's profitability. A Good demand forecasting requires the expertise and reliability of the planning staff. The research is a case study in a transformer manufacturer in Indonesia, which planned to apply forecasting process and suitable tools for their products. The study demonstrated a systematic step required in forecasting the four studied products. For each product, 6 forecast models were evaluated and the best model was selected by optimizing forecast parameters which give the least forecast errors. The chosen forecasting model is a simple model but fairly complete in forecasting evaluation, to accommodate both trend and seasonal possibility in product forecasting. The study offers the basis for the company to establish forecasting processes and tools for its products. It also recommended the studied company to perform and monitor its forecasting process for continuous improvement to its business process.

Keywords: Forecasting, Exponential Smoothing, , Holt, Winter 


\section{INTRODUCTION}

Accurate demand forecast is essential in industries, since it directly related to financial performance of the company. Demand forecasting is a process of predicting the future state of events which although unknown, can be predicted. In a nutshell, forecasting activity is an essential element for company in making its business planning, decision and strategy (Mancuso \& Werner, 2013)

There are three main areas in demand process, namely demand planning, demand forecasting and demand management. Demand planning is a multiple steps operational supply chain management process used to create the reliable forecast. Demand forecasting is a prediction, projection into the future activity, event or occurrence. Demand management is an emerging topic in supply chain management. It is focused on a fast and adequate integration of supplier needs to balance and strategically align demand with operational capability in the supply chain.

According to (APICS, 2011) demand is "need for a particular product or component". The need can be originated from different kind of sources such as customer orders or forecast, or even distribution replenishment requirement between regional warehouses or sales branches.

Demand planning typically uses the skill of forecast and experience in order to give demand estimation for an item or various items at different points along the supply chain, using several techniques. Often, families of items are aggregated in doing this planning. Aggregation also may occur by geographical region or by life cycle stage.

Source of demand variability are competition, seasonality, life cycle trends, external factors, promotions, disasters and distance. Aspects of demand planning are supply chain dynamics, forecasting, collaborative demand planning, and role of marketing (APICS, 2011).

The direct objective of demand forecasting is to transfer the consumer's prediction to manufacturing side, so supply can be arranged accordingly. Forecasting typically is done using historical data (Arief, M., Supriyadi, Cahyadi, D., 2017). The activity can be done using various methods, ranging from informal judgment, expert intuition and opinion using macro-economic indicators, or simply forecasting based on historical data (Mancuso \& Werner, 2013).

Demand management requires the coordination of marketing activities, demand planning, and demand forecasting management accordingly (Mentzer, J.T. \& Moon, 2005). As further restated by (Melo, 2016) there are two faces of demand management : demand management as the integration of marketing and supply management and as a process or component of the supply chain management. Demand managen nent necessitates synergies between operation and marketing management in order to better understand the market and develop action plans (Anning, Okyere, \& Annan, 2013; Chong \& Zhou, 2014). It is part of supply chain management process that balance what customer needs with supply capability and how to execute the plan with minimal disruption possible using the right management process (Croxton, Lambert, García-Dastugue, \& Rogers, 2002)

Forecast is the art and science of predicting the future events. Forecasting may involve taking historical data and projecting them into the future with mathematical model." (Heizer \& Render, 2014). From the statement above, the researchers conclude that forecast is a study about predicting the future based on what happened in the past and make science prediction out of it. According to (Niswatin, 2015) all of the forecast method is using historical data to forecast in the future that contains uncertainty. So, forecast method assuming that past condition was not different with future condition except explicit variables are using in that period. Forecast for management must be a systematic system. On the other hands, a forecast not to be considered permanent or static.

(Amstrong, 2001) suggested to consider six aspects when evaluating the most suitable forecast methods, namely convenience, market popularity, 
structured judgment, statistical criteria, relative track records and guidelines from previous studies. He also argued that certain statistical criteria, e.g. distribution of errors, can be useful in certain occasions. Nevertheless, he proposed the forecasting decision tree in finding the most suitable method for the company. Sales forecast is also a critical input to the Sales and Operation (S\&OP) process, and typically made by marketing and sales department as the frontliners to the customers (Mentzer, J.T. \& Moon, 2005).

Forecasting methods can be differentiated into Qualitative Method and Quantitative Method. Qualitative methods are typically used for new products, when hard data are lacking, for checking result from quantitative methods, or for long term forecasting.

Examples of qualitative method are (Heizer \& Render, 2014):

1. Jury of executive opinion, where foreeast is done by a small group of high level/managers who provide a group estimate upon the customer demand.

2. Delphi method, where forecast is done based on a group of panels of experts

3. Force composite is when forecast is based on estimation done by sales force

4. Market survey is when forecasting is done based on (potential) eustomer estimates on how they plan their purchase.

Quantitative forecasting method can be categorized into 2, namely time-series and associative model. Time series forecasting is "A forecast based on internal factors, such as an average of past sales", whilst Associative forecasting is "A forecast method based on correlated leading indicators ",

Some of the time series methods are:

1. Naïve Approach is a forecasting technique which assumes that demand in the next period is equal to demand in the most recent period. Naïve approach method is the simplest way to forecast, and this method is the most cost effective and efficient objective forecasting model (Heizer \& Render, 2014).

2. Moving averages is a forecasting method that uses an average of the $n$ most recent periods of data to forecast the next period. It's useful if we can assume that markets demand will stay steady over time (Chopra \& Meindl, 2016). Common $n$ $=3$ was used in moving average model (Sundari, S. S., Susanto, \& Revianti, 2015)

3. Weighted moving averages is modification from the previous method by assigning weight to the historical data. This technique is considered to be more responsive to changes because more recent peíods are assigned a heavier weight. Choice of weights is somewhat arbitrary because there is no set formula to determine them. Therefore, deciding which weights to use requires some experiences (Heizer \& Render, 2014)

4. Exponential smoothing is in a nutshell a weighted moving average forecasting technique in which data points are weighted by an exponential function. It involves very little record keeping of past data and is easy to use (Heizer \& Render, 2014)

5. Exponential smoothing with trend adjustment (Holt method). A variation from Holt's linear trend method is achieved by allowing level and the slope to be multiplied, the trend in the forecast function is now exponential rather than linear, so that the forecasts project a constant growth rate rather than a constant slope (Hyndman \& Athanasopoulos, 2014)

6. Holt with damped trend is the forecast method which display a constant trend (increasing or decreasing) indefinitely into the future. Motivated by this observation, (Gardner, McKenzie, Jr., \& McKenzie, 1985) introduced a parameter that "dampens" the trend to a flat line sometime in the future (Hyndman \& Athanasopoulos, 2014)

7. As restated in (Valakevicius \& Brazenas, 2015), the Holt-Winters model was developed to 
incorporate possible trends and seasonality from exponentially weighted averages (Holt, 2004; Kalekar, 2004). Holt-Winter methods which involves trend and seasonality by introducing three smoothing equation. Holt Winter is also grouped into additive and multiplicative model. The additive model is the one having a constant seasonal component is constant, whilst the multiplicative model is having a proportional seasonal component (against trend level).

One of the industry that needs demand forecasting is electricity sectors in Indonesia. With the steady growth of it population, power consumption's need in the country is prevalent. However, the needs of each energy types and sectors has different trends due to cannibalism effect amongst energy types and technology advancement. Figure 1 illustrated the key figures of Indonesia electricity indicating a healthy growth.

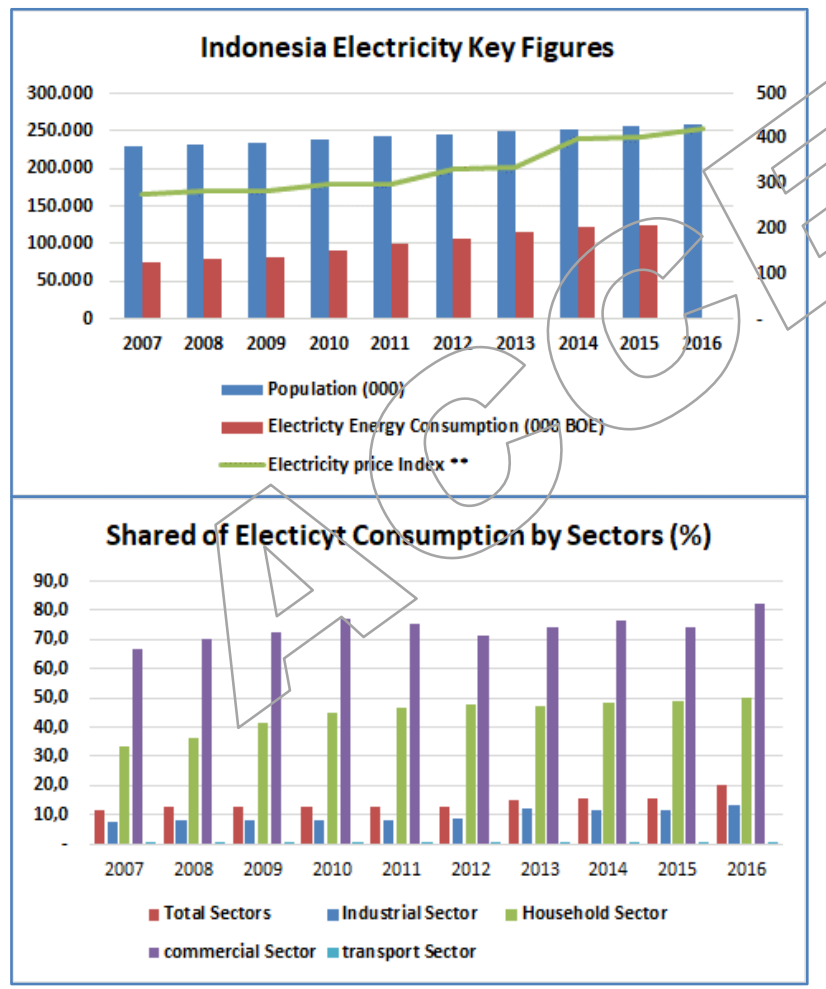

Figure 1. Indonesia Electricity Key Figures \& Consumption

Source : (Ministry Of Energy and Mineral Resources Republic of Indonesia, 2017)
This research is a case study of a transformer manufacturer in Indonesia. The company manufactures distribution transformers and related products for power distribution.

Being one of the player in the electricity sector, the company has a need to establish a good forecasting process and tools for its product to improve its business process and profitability. Some of the company's products shown seasonality pattern, calling for a good forecasting practice in order to manage its supply chain. Figure 2 shows historical demand for four of its products, i.e. : KVA 25, KVA50, KVA100 and KVA 160.

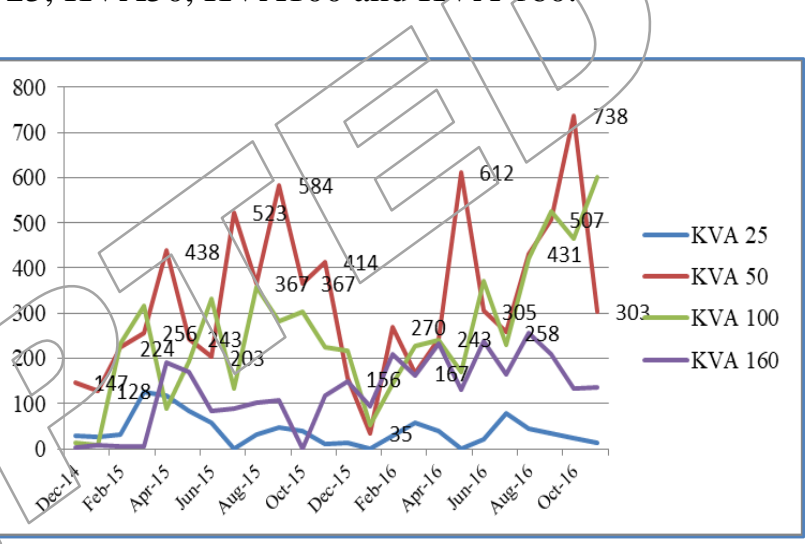

Figure 2. Historical Demand 4 products of the studied company

The objective of this research is to assists the studied company implement a good forecast practice and tools for its 4 products.

\section{RESEARCH METODOLOGY}

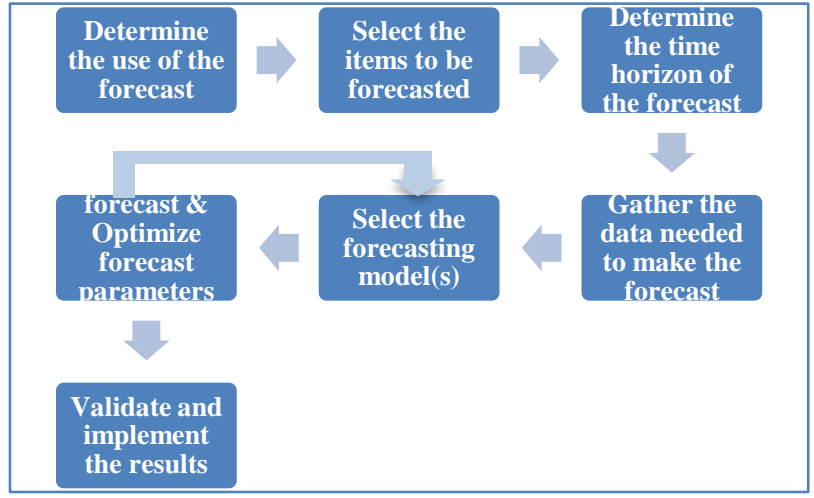

Figure 3. Proposed Steps and Methodology 
The case study demonstrated a systematic steps of forecasting practice towards 4 products of the studied company, as illustrated in Figure 3.

Six (6) forecast models were tested for each product, using the following formulas:

1. Moving Averages

$$
\text { Forecast }=\frac{\sum \text { demand in previous } n \text { period }}{n}
$$

Where $\mathrm{n}$ is the number of period in the moving average.

2. Weighted Moving Average

$$
\text { Forecast }=\frac{\sum((\text { Weight for period } n)(\text { Demand in period } n))}{\sum \text { Weights }}
$$

3. Exponential Smoothing

New forecast $=$ Last period's forecast $+\alpha$ Last period's actual demand - last period's for ecast)

Where $\alpha$ is a smoothing constant between the value of 0 and 1 chosen by the demand planner. The formula for exponential smoothing can also be written mathematically as:

Where: $\quad F_{t}=F_{t-1}+\alpha\left(A_{t-1}-F_{t-1}\right)$

$$
\begin{aligned}
& \mathrm{F}_{\mathrm{t}}=\text { new forecast } \\
& \mathrm{F}_{\mathrm{t}-1}=\text { previous period's forecast } \\
& \alpha=\text { smoothing (or weighting) constant }(0 \leq \\
& \quad \alpha \leq 1) \\
& \mathrm{A}_{\mathrm{t}-1}=\text { previous period's actual demand }
\end{aligned}
$$

4. Exponential Smoothing with trend adjustment (Holt's Model)

Holt model is a forecast method that combines the weighted average of the current period's actual value and forecast, with a trend adjustment, using the following formulas:

$$
\begin{aligned}
& F I T_{t}=F_{t}+T_{t} \\
& F_{t}=\alpha\left(A_{t-1}\right)+(1-\alpha)\left(F_{t-1}+T_{t-1}\right) \\
& T_{t}=\beta\left(F_{t}-F_{t-1}\right)+(1-\beta) T_{t-1}
\end{aligned}
$$

Where:

$F_{t}=$ Exponentially smoothed forecast of the data series in period $t$

$T_{t}=$ Exponentially smoothed trend in period $t$

$A_{t}=$ Actual demand in period $t$

$\alpha=$ Smoothing constant for the average $(0 \leq \alpha \leq$ 1)

$\beta=$ Smoothing constant for the trend $(0 \leq \beta \leq 1)$

5. Holt with Damped Trend

This method uses the same formula with Holts model, but with addition of damping coefficient $\phi$.

$$
\begin{aligned}
& F I T_{t}=F_{t}+\sum \phi T_{t} \\
& F_{t}=\alpha\left(A_{t-1}\right)+(1-\alpha)\left(F_{t-1}+\phi T_{t-1}\right) \\
& T_{t}=\beta\left(F_{t}-F_{t-1}\right)+(1-\beta) \phi T_{t-1}
\end{aligned}
$$

6. Holt-Winter

This method is used to analyze whether there is seasonality in the forecasting, using the following formula:

$$
\begin{aligned}
& F_{t+m}=L t+\left(m T_{t}\right) * S_{t+m-s} \\
& L_{t}=\alpha\left(D_{t}-S_{t-1}\right)+(1-\alpha)\left(L_{t-1}+T_{t-1}\right) \\
& T_{t}=\beta^{*}\left(L_{t}-F_{t-1}\right)+(1-\beta) T_{t-1} \\
& S_{t}=\gamma\left(D_{t} / L_{t}\right)+(1-\gamma) S_{t-1}
\end{aligned}
$$

where $\alpha$ is parameter for forecast level, $\beta$ for trend and $\gamma$ for seasonality.

The best forecast model is determined by calculating the forecast error, i.e :

$$
\begin{aligned}
\text { Forecast error } & =\text { Actual demand }- \text { Forecast value } \\
& =A_{t}-F_{t}
\end{aligned}
$$

The three most common measures of forecast error are mean absolute deviation (MAD), mean squared error (MSE), and mean absolute percentage error (MAPE), which has the following elaboration:

1. Mean Absolute Deviation (MAD)

Mean absolute deviation is calculated by taking the sum of the absolute values of the individual forecast deviations and dividing it with the number of periods of data $(n)$ (Heizer, Render, $2014: 151)$ :

$$
\mathrm{MAD}=\frac{\sum \mid \text { Actual }- \text { Forecast } \mid}{n}
$$


2. Mean Squared Error (MSE)

The mean squared error is a another measurement of forecast error. It is calculated by averaging the squared differences between the forecasted and observed values, using the following formula :

$$
\text { MSE }=\frac{\sum(\text { Forecast errors })^{2}}{n}
$$

3. Mean Absolute Percent Error (MAPE)

The mean absolute percent error is computed by comparing the average of the absolute difference between forecast and actual values, expressed as a percentage of the actual values. The formula for mean absolute percent error mentioned is as following:

$$
\text { MAPE }=\frac{\sum_{i=1}^{n} 100-\frac{\mid \text { Actuali-Forecasti }}{A}}{n}
$$

\section{RESULTS AND DISCUSSION}

For each of the studied products, different forecast models were tested and evaluated. The selected model is the one which give the least foreeast errors.

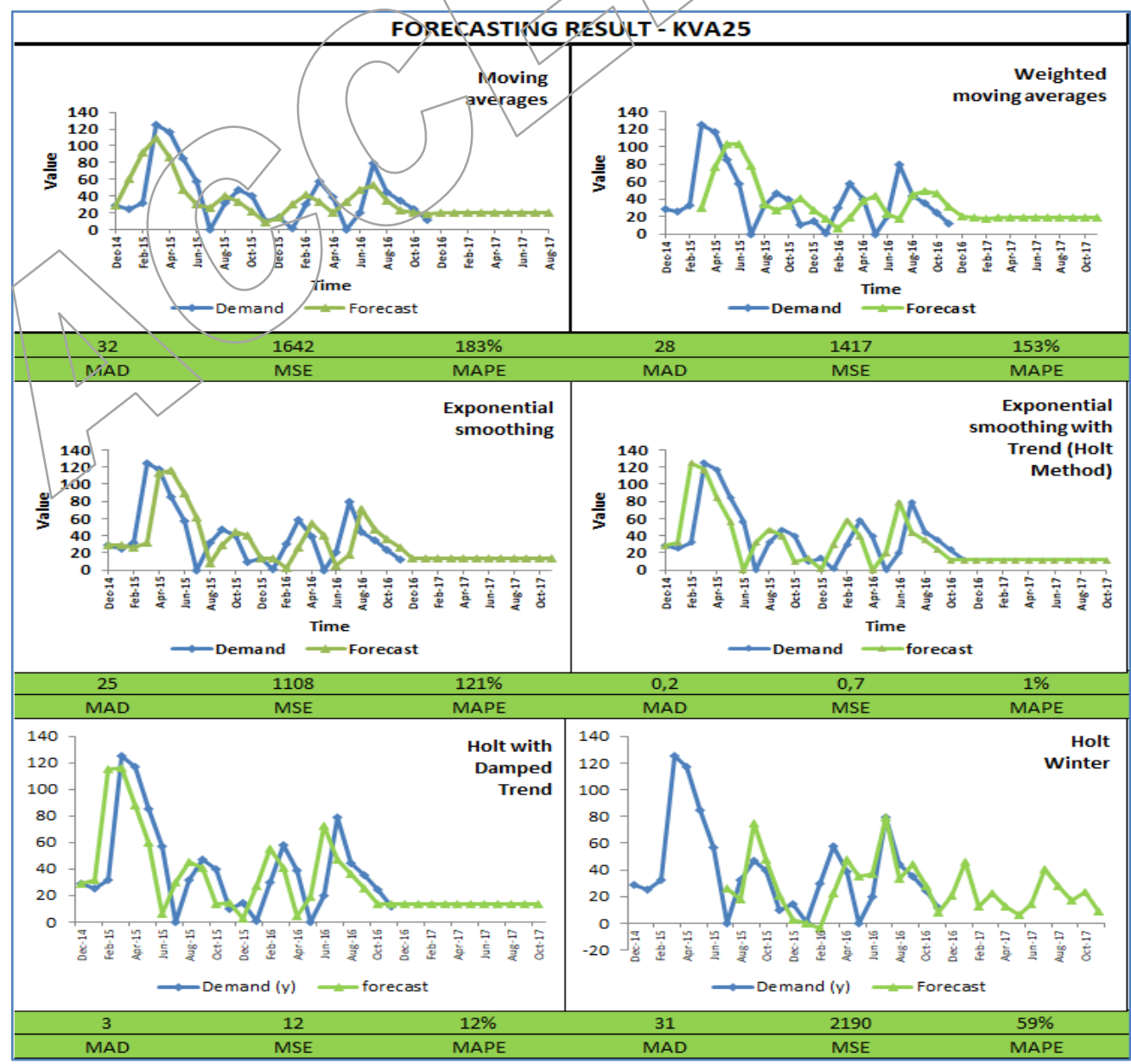

Figure 4. Summary of Forecast for Product KVA25 


\section{Forecast Result for Product KVA25 (sample calculation)}

6 forecast models were tested on this product in order to review and evaluate which model is the best one as well as to finetune and optimize the respected forecast parameters. Summary results for product KVA25 are illustrated in Figure 4. For (Weighted) moving average model, the formula is simple and straight forward. For exponential smoothing models, forecast parameter $\alpha$ was optimized by choosing the value that will give the least forecast errors. The optimization was done using Microsoft excel solver tool. Figure 5 shows summary evaluation of Exponential Smoothing model with different value of $\alpha$ which optimize the forecast error MAD, MSE, and MAPE. For this product, $\alpha=0.87$ was chosen as it gives the best combination of forecast error.

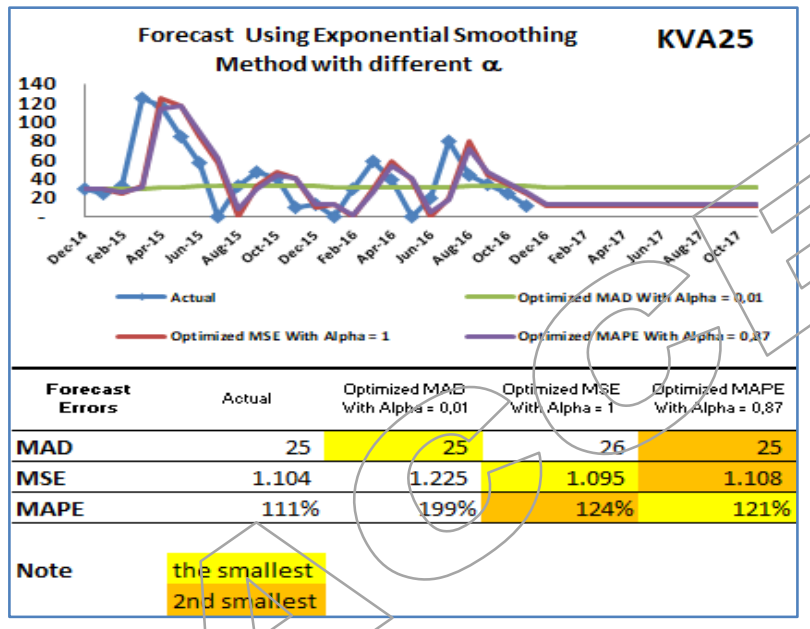

Figure 5. Evaluation of "Exponential Smoothing" Model on Product KVA 25

With the same principles, forecast parameter $\beta$ was optimized in "Exponential smoothing with trend/Holt" model and result is summarized in Figure 6. $\beta=1$ was chosen for this product as it gives the least forecast errors in term of MAD, MSE \& MAPE.

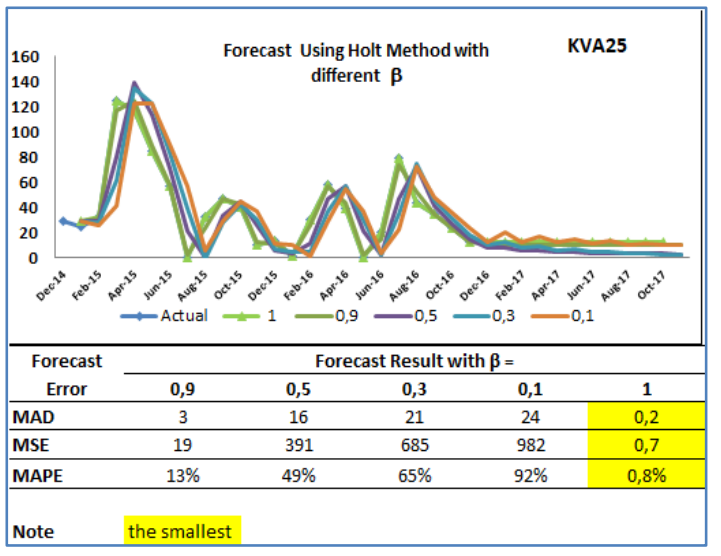

Figure 6. Evaluation of "Holt" Model on Product KVA 25

As growth in trend model may not be always linearly against time, another model called "Holt with damped trend" model was also tested. This model is similar with "Holt" model, but with introduction of another forecast parameter called $\phi$ illustrating damped coefficient.

The last model being evaluated is "Holt-Winter" models which capture possibility of both trend and seasonality of a product. With the same principle using Microsoft excel solver, forecast parameters $\alpha, \beta, \gamma$ was evaluated to choose the best forecast error. Summary evaluation of "Holt-Winter" model for product KVA 25 is illustrated in Figure 7.

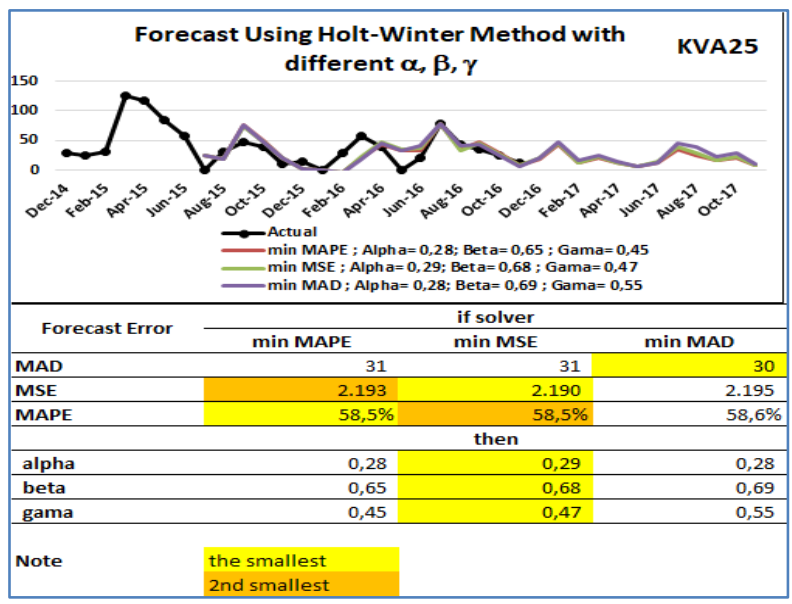

Figure 7. Evaluation of "Holt-Winter" Model on Product KVA 25 


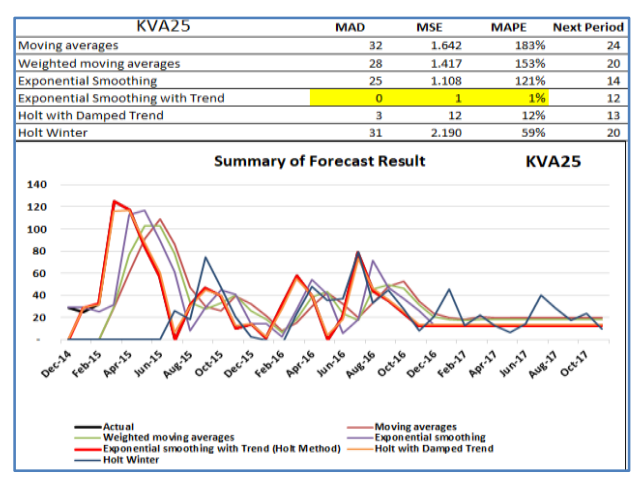

Figure 8. Summary of Forecast Model for Product KVA 25

The summary of forecast model evaluation for product KVA25 against resulted forecast errors is illustrated in Figure 8, upon which "Exponential Smoothing with Trend/Holt" model was selected as the best model for KVA25.

\section{Forecast Result for Other 3 Products}

With similar approaches, the six possible forecast models were tested against the other 3 products and the results are summarized in Figure 9-11.

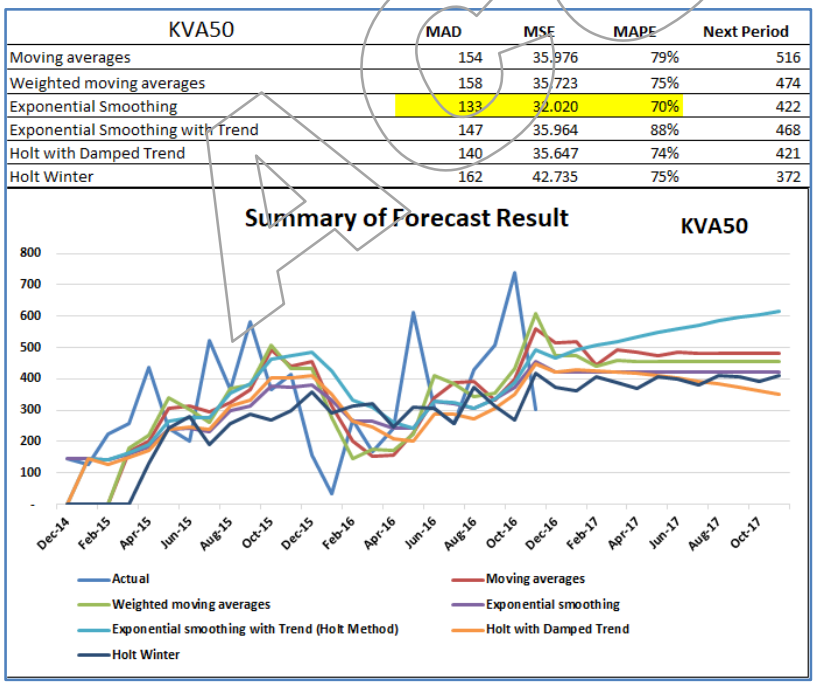

Figure 9. Summary of Forecast Model for Product KVA 50

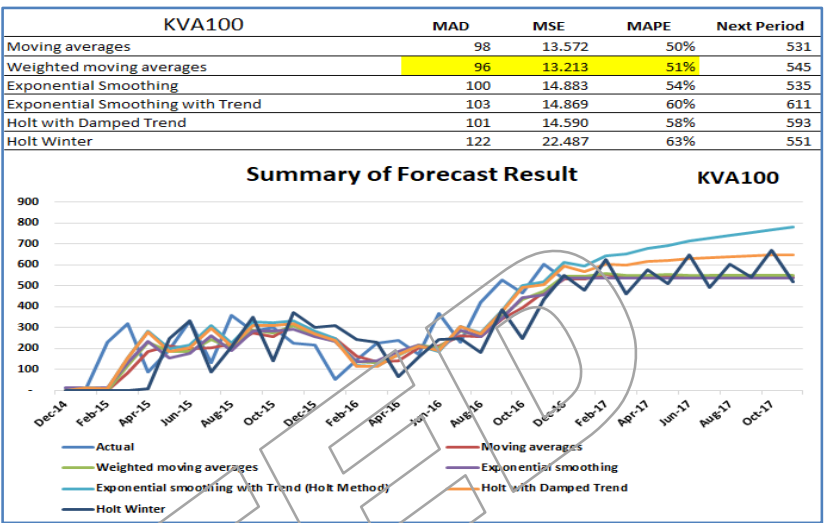

Figure 10. Summary of Forecast Model for Product

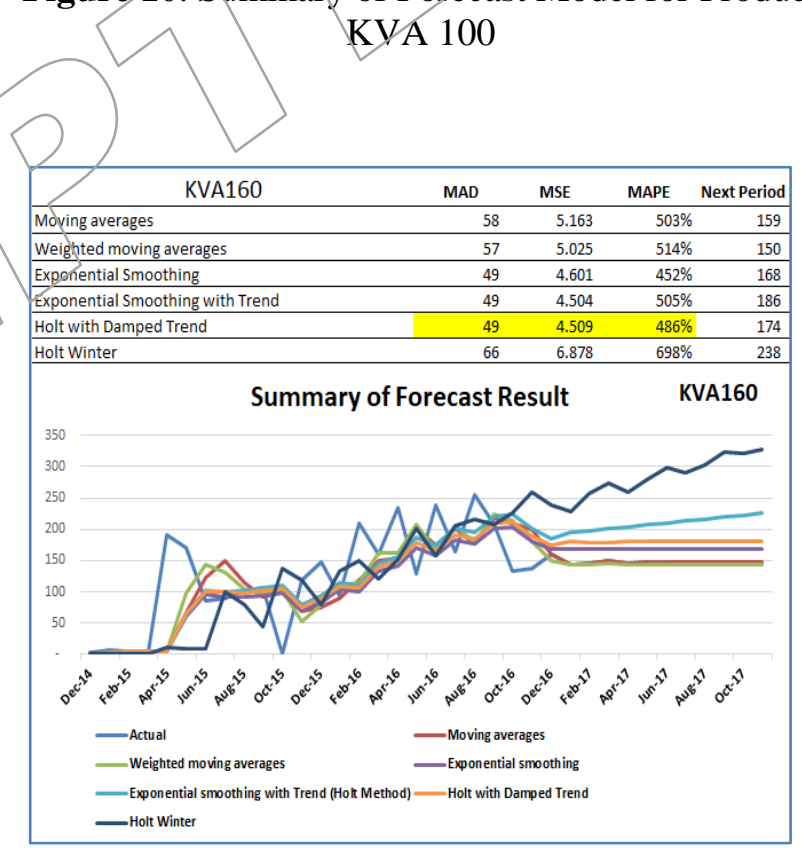

Figure 11. Summary of Forecast Model for Product KVA 160

\section{Insights and Discussions}

Forecasting practice is a continuous improvement activity in a firm. Every month demand planner, as new data from pervious actual month derived, the planner must recheck the forecast models for each product whether they are still valid. Adjustment to the models (e.g. changing the models or parameters) is common and necessary for continuous improvement.

Deciding which models to be tested towards which products requires a mastery of forecasting tools and insights against product behaviour. Nevertheless, demand planners are obliged to test the products against enough forecast models. 
The recommended six forecast models can be considered simple yet complete set of choice. (Weighted) moving average is simple to be served as bases against other more sophisticated models. Exponential smoothing compensates the drawback of lagging for product with trend behaviour. Holt and Winter models give opportunity to capture trend and seasonality pattern of a product.

The steps and approaches taken in selecting which method is the most suitable for each products should give a simple and practical procedure / guideline for the studied company to perform alternative forecasting approach than their current process. A good and regular forecasting review practice can then help the studied company to manage better supply planning along its supply chain.

\section{CONCLUSION}

The research was suecessfully implement and recommend systematic steps required to perform a sound forecasting tools for the studied company. It is recommended for the studied company to evaluate more complete forecasting tools such as exponential smoothing, Holt, or Holt-winter methods in order to accommodare possible trend and seasonality pattern.

In selecting which forecast methods is the most suitable for each product, it is recommended to regularly adjust forecast parameters (e.g. $\alpha, \beta, \gamma$ ) by monitoring the resulted forecast accuracy.

\section{ACKNOWLEDGEMENT}

The authors wish to thank Edx Supply Chain for giving a complete understanding of forecasting techniques which combine academic and practical point of view.

\section{REFERENCES}

[1] Mancuso, A. C. B., \& Werner, L. (2013). Review of Combining Forecasts Approaches. Independent Journal of Management \& Production, 4(1), 248-277.

[2] APICS. (2011). Supply Chain Management Fundamentals - CSCP Module 1 (V 2.2-2011).

[3] Arief, M., Supriyadi, Cahyadi, D., Analisis
Perencanaan Persediaan Batubara FX Dengan Metode Material Requirement Planning. Jurnal Manajemen Industri Dan Logistik, 1 (2), 53-60

[4] Mentzer, J.T. \& Moon, M. A. (2005). Sales Forecasting Management - A Demand Management Approach (2nd ed.). CA: Thousand Oaks, CA: Sage.

[5] Melo, D. D. C (2016). What makes demand management in the supply chain possible? A multiple-case study of critical success factors. Gest. Prod, 23(3), 570-587.

[6] Anning, K. S., Okyere, S., \& Annan, J. (2013). Demand Chain Management Model: A Tool for Stakeholders, Value Creation. International Journal of Business and Social Research, 3(12), 37-47.

[7] Chong, A. Y. L., \& Zhou, L. (2014). Demand chain management: Relationships between external antecedents, web-based integration and service innovation performance. International Journal of Production Economics, 154, 48-58.

[8] Croxton, K. L., Lambert, D. M., GarcíaDastugue, S. J., \& Rogers, D. S. (2002). The Demand Management Process. The International Journal of Logistics Management, 13(2), 51-66.

[9] Heizer, J., \& Render, B. (2014). Operations Management - Sustainability \& Supply Chain Management (11th ed.). Essex, England: Pearson.

[10] Niswatin, R. K. (2015). Sistem Pendukung Keputusan Peramalan Produksi Air Minum Menggunakan Metode Trend Moment. Simetris, 6(2), 337-344.

[11] Amstrong, J. . (2001). Principles of Forecasting: A Handbook for Researchers and Practitioners. Kluwer Academic Publishers (Vol. 18).

[12] Chopra, S., \& Meindl, P. (2016). Supply Chain Management: Strategy, Planning, and Operation. Pearson Education, Inc.

[13] Sundari, S. S., Susanto, \& Revianti, W. (2015). Sistem Peramalan Persediaan Barang Dengan Weight Moving Average Di Toko The Kids 24. In Konferensi Nasional Sistem \& Informatika (p. 598-603.).

[14] Hyndman, R. J., \& Athanasopoulos, G. 
(2014). Forecasting: Principles and Practice. OTexts, (july 1994), 46-51.

[15] Gardner, E. S., McKenzie, E., Jr., \& McKenzie, E. Forecasting Trends in Time Series, 31 Management Science $\S$ (1985).

[16] Valakevicius, E., \& Brazenas, M. (2015). Application of the Seasonal Holt-Winters Model to Study Exchange Rate Volatility. Inzinerine Ekonomika-Engineering Economics, 26(4), 384-390.

[17] Holt, C. C. (2004). Forecasting seasonals and trends by exponentially weighted moving averages. International Journal of Forecasting, 20(1), 5-10

[18] Kalekar, P. (2004). Time series forecasting using Holt-Winters exponential smoothing. Kanwal Rekhi School of Information Technology, (4329008), 1-13.

[19] Ministry Of Energy and Mineral Resources Republic of Indonesia. (2017). Handbook of Energy and Economic Statistics of Indonesia 2017. (S. E. Prabowo, Ed.). Jakarta. 